GLOBAL PERSPECTIVES

Section Editors

Johan A. Aarli, MD

Oded Abramsky, MD,

PhD, FRCP

\title{
Global polio perspective
}

[a]

M. Steven Oberste, $\mathrm{PhD}$

Howard L. Lipton, MD

Correspondence to

Dr. Lipton:

hlipton@uic.edu

\section{ABSTRACT}

The results of the Global Polio Eradication Initiative that began in 1988 when there was transmission of 350,000 polio cases in 125 countries and has culminated in endemic transmission of only 223 polio cases in 3 countries in 2012 are reviewed. Neurology ${ }^{\circledR}$ 2014;82:1831-1832

Poliovirus is primarily transmitted by the fecal-oral route, though respiratory transmission may also play a role. Like all enteroviruses, the vast majority of infections are asymptomatic or result in only mild illness-fewer than $1 \%$ of infected individuals become paralyzed, with some variability by serotype (about $0.5 \%$ for type 1 , $0.05 \%$ for type 2 , and $0.2 \%$ for type 3 ). The major risk factors for infection are poor sanitation (i.e., exposure to virus in raw sewage), high population density, lack of immunization (often due to poor health infrastructure and poor routine immunization), and warm climate.

Since the Global Polio Eradication Initiative (GPEI) began with the goal of eliminating wild poliovirus (WPV) transmission, polio cases have decreased from 350,000 in 125 countries in 1988 to 223 in 2012. In 2012, only 3 countries had endemic transmission of WPV that had never been interrupted: Nigeria, Afghanistan, and Pakistan. India had long supported endemic transmission but WPV has not been detected since January 2011 and the country was declared polio-free in 2012. Type 2 WPV was last seen in 1999; there has not been a type 3 case reported in Asia since April 2012 and in Africa since November 2012. In 2013, there were a total of 45 cases of acute flaccid paralysis due to WPV in 5 countries - the 3 endemic countries plus Somalia and Kenya, where wild virus has been reintroduced from Nigeria (www.polioeradication.org; data as of June 4, 2013). ${ }^{1}$ This contrasts with 650 cases in 2011, when WPV circulated in the then-4/endemic countries and caused outbreaks in 12 additional countries, including 130 cases in Chad, 89 cases in Democratic Republic of the Congo, 61 cases elsewhere in sub-Saharan Africa, and 21 cases in western China (linked to virus imported from Pakistan).

The primary tool in global polio eradication has been the trivalent oral polio vaccine ( $\mathrm{tOPV})$, often delivered in mass campaigns. In recent years, monovalent vaccines (mOPV1 and mOPV3) and bivalent vaccine (types 1 and 3) have also been used in some countries. OPV is relatively inexpensive, can be given by volunteer vaccinators with minimal training, and elicits a mucosal immune response that protects from disease and presumably also reduces transmission should the immunized person be exposed to WPV. Like WPV, vaccine virus is excreted in stool for 4-8 weeks. One disadvantage of the live, attenuated vaccine is that the Sabin vaccine strains differ from the wild, neurovirulent strains from which they were derived at a very small number of sites. As a result, in rare instances ( $<-1$ per 900,000 first OPV doses), vaccine-associated paralytic poliomyelitis (VAPP) can occur in the primary vaccinee or in close contacts (contact VAPP). In a community with yery low vaccine coverage, vaccine-related virus can establish transmission, resulting in phenotypic reversion through loss of attenuating substitutions. Such vaccine-derived polioviruses (VDPVs) are genetically similar to their Sabin vaccine progenitor strains but they have acquired properties of WPV, namely full neurovirulence and efficient transmission. ${ }^{2}$ VDPV of any of the 3 poliovirus serotypes may emerge but VDPV2 is the most common, probably because the type 2 Sabin strain has fewer attenuating mutations than types 1 and 3 . The primary risk factors for emergence of circulating VDPVs (cVDPVs) are the absence of the corresponding serotype of WPV (i.e., lack of natural immunity in the population), low vaccine coverage, and use of OPV. In 2012, cVDPVs were identified in 8 countries (66 of 68 cases were due to type 2). ${ }^{1,3}$

VDPVs can also arise in persons with primary immunodeficiency disorders (antibody deficits) who receive OPV directly—often before diagnosis of their immunodeficiency—or who are exposed secondarily through an immunized close contact, such as a sibling or child. Such iVDPV strains can evolve to reacquire neurovirulence within the immunodeficient person, posing a serious paralysis risk to the individual, and can also be excreted for

From the Centers for Disease Control and Prevention (M.S.O.), Atlanta, GA; and the Department of Microbiology and Immunology (H.L.L.), University of Illinois at Chicago.

Go to Neurology.org for full disclosures. Funding information and disclosures deemed relevant by the authors, if any, are provided at the end of the article. 
months to years, posing a risk to the community. In 2006, the National Research Council recommended development of polio antivirals to treat immunodeficient people who are chronically shedding poliovirus and for possible use in others exposed to live poliovirus, such as through an unintentional laboratory exposure, or as a tool (likely in conjunction with inactivated polio vaccine) to control community VDPV outbreaks in the post-OPV era. ${ }^{4,5}$ One compound is currently in a phase II clinical trial and several other compounds are in preclinical or early clinical development as alternatives or as possible components of a drug combination.

As the "endgame" in GPEI approaches, many questions about fundamental issues of the pathogenesis of poliovirus infection remain unanswered. These include the cellular sites of viral replication, route of neural invasion from blood, mechanisms of neurovirulence and viremia, and others. ${ }^{6}$ However, the prospects for answering these questions do not appear promising. For this generation of physicians, it is worth pointing out that in several recent outbreaks of WPV, a majority of cases have been in adults, in whom paralysis is known to be more widespread and severe and the case-fatality rate higher than in young children. ${ }^{7,8}$ This observation is not new and it was noted at the advent of poliovirus vaccination that paralytic poliomyelitis had been increasing in incidence in older children and adults for 25 years. ${ }^{9}$ Although the increases in adults during recent outbreaks could be due to gaps in poliovirus immunization, the chronological increase in age of paralytic poliomyelitis remains enigmatic since this was occurring prior to poliovirus vaccination.

\section{STUDY FUNDING}

H.L.L. supported by grants from NINDS (NIH).

\section{DISCLOSURE}

The authors report no disclosures relevant to the manuscript. Go to Neurology.org for full disclosures.

\section{REFERENCES}

1. World Health Organization. Global Polio Eradication Initiative. Available at: http://www.polioeradication.org/.

2. Kew OM, Sutter RW, de Gourville EM, Dowdle WR, Pallansch MA. Vaccine-derived polioviruses and the endgame strategy for global polio eradication. Annu Rev Microbiol 2005;59:587-635.

3. Centers for Disease Control and Prevention. Update on vaccine-derived polioviruses worldwide, April 2011-June 2012. MMWR Morb Mortal Wkly Rep 2012;61:741-746.

4. National Research Council. Exploring the Role of Antiviral Drugs in the Eradication of Polio. Washington, DC: The National Academies Press; 2006.

5. Collett MS, Neyts J, Modlin JF. A case for developing antiviral drugs against polio. Antivir Res 2008;79:179-187.

6. Nathanson $\mathrm{N}$. The pathogenesis of poliomyelitis: what we don't know. Adv Virus Res 2008;71:1-50.

7. Centers for Disease Control and Prevention. Outbreak of polio in adults: Namibia, 2006. MMWR Morb Mortal Wkly Rep 2006;55:1198-1201.

8. Patel MK, Konde MK, Didi-Ngossaki BH, et al. An outbreak of wild poliovirus in the Republic of Congo. Clin Infect Dis 2012;55:1291-1306.

9. Weinstein J. Influence of age and sex on susceptibility and clinical manifestations in poliomyelitis. N Engl J Med 1957;257:47-52. 


\section{Neurology}

Global polio perspective

M. Steven Oberste and Howard L. Lipton

Neurology 2014;82;1831-1832

DOI 10.1212/WNL.0000000000000426

\section{This information is current as of May 19, 2014}

\section{Updated Information \& Services}

\section{References}

Subspecialty Collections

Permissions \& Licensing

Reprints including high resolution figures, can be found at: http://n.neurology.org/content/82/20/1831.full

This article cites 7 articles, 0 of which you can access for free at: http://n.neurology.org/content/82/20/1831.full\#ref-list-1

This article, along with others on similar topics, appears in the following collection(s):

All epidemiology

http://n.neurology.org/cgi/collection/all_epidemiology

All Infections

http://n.neurology.org/cgi/collection/all_infections

Spinal cord infarction

http://n.neurology.org/cgi/collection/spinal_cord_infarction

Information about reproducing this article in parts (figures,tables) or in its entirety can be found online at:

http://www.neurology.org/about/about_the_journal\#permissions

Information about ordering reprints can be found online:

http://n.neurology.org/subscribers/advertise

Neurology ${ }^{\circledR}$ is the official journal of the American Academy of Neurology. Published continuously since 1951, it is now a weekly with 48 issues per year. Copyright @ 2014 American Academy of Neurology. All rights reserved. Print ISSN: 0028-3878. Online ISSN: 1526-632X.

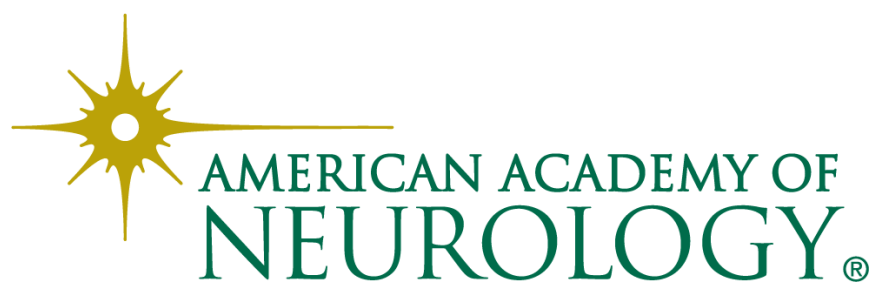

